\begin{tabular}{|c|c|c|c|c|}
\hline Variable & $\begin{array}{l}\text { Total } \\
\text { population }\end{array}$ & Cardiac & $\begin{array}{l}\text { Non- } \\
\text { cardiac }\end{array}$ & $\begin{array}{l}\mathrm{p} \\
\text { value }\end{array}$ \\
\hline $\begin{array}{l}\text { Days between } \mathrm{PCl} \text { and readmission average } \\
\text { in days ( } \mathrm{SD} \text { days) }\end{array}$ & $11.6(8.1)$ & $\begin{array}{l}10.8 \\
(8.1)\end{array}$ & $\begin{array}{l}12.2 \\
(8.1)\end{array}$ & 0.09 \\
\hline Length of stay average in days (SD days) & $5.3(12.4)$ & $\begin{array}{l}4.0 \\
(6.7)\end{array}$ & $\begin{array}{l}6.4 \\
(15.9)\end{array}$ & 0.08 \\
\hline Angiogram (\%) & $61(14.4)$ & $\begin{array}{l}54 \\
(31.8)\end{array}$ & $7(2.9)$ & $<0.01$ \\
\hline Echocardiogram (\%) & $28(6.6)$ & $\begin{array}{l}20 \\
(11.8)\end{array}$ & $8(3.3)$ & $<0.01$ \\
\hline Cardiologist review (\%) & $167(39.3)$ & $\begin{array}{l}127 \\
(74.7)\end{array}$ & $40(16.6)$ & $<0.01$ \\
\hline Cardiac diagnosis (\%) & $170(41.4)$ & & & \\
\hline Discharged home (\%) & $392(92.2)$ & $\begin{array}{l}159 \\
(93.5)\end{array}$ & $\begin{array}{l}233 \\
(96.7)\end{array}$ & 0.27 \\
\hline Died at twelve months (\%) & $7(1.7)$ & $5(2.9)$ & $2(0.8)$ & 0.29 \\
\hline
\end{tabular}

Conclusion Cardiac readmission's continue to occur after 10\% of percutaneous coronary intervention procedures. Whilst the prognosis is good, measures to reduce these rates are required.

\section{CLINICAL OUTCOMES FOLLOWING PRIMARY PERCUTANEOUS CORONARY INTERVENTION: A COMPARISON OF CLOPIDOGREL, PRASUGREL AND TICAGRELOR}

${ }^{1}$ Arvindra Krishnamurthy*, 'Claire M Keeble, ${ }^{2}$ Natalie Burton-Wood, ${ }^{2}$ Kathryn Somers, ${ }^{2}$ Michelle Anderson, ${ }^{2}$ Charlotte Harland, ${ }^{2}$ James M McLenachan, ${ }^{2}$ Jonathan M Blaxill, ${ }^{2}$ Daniel J Blackman, ${ }^{2}$ Christopher J Malkin, ${ }^{1}$ Stephen B Wheatcroft, ${ }^{1} J o h n$ P Greenwood. ${ }^{1}$ University of Leeds; ' Leeds Teaching Hospitals NHS Trust

\subsection{6/heartinl-2017-311726.26}

Introduction The West Yorkshire Primary Percutaneous Coronary Intervention outcomes study was established to identify factors that are associated with clinical outcomes following primary percutaneous coronary intervention (PPCI) for ST-segment elevation myocardial infarction (STEMI). We assessed the association of procedural oral P2Y12-inhibitor with clinical outcomes in a large consecutive patient-series.

Methods Demographic and procedural data for all patients undergoing PPCI between 1-1-2009 and 31-12-2011, and 1-12013 and 31-12-2013, in Leeds General Infirmary, were collected prospectively. Minimum 30 day follow-up data were collected for all. Patients with pre-procedural cardiogenic shock and/or cardiac arrest were excluded. Clinical endpoints were 30 day major adverse cardiovascular event (MACE) defined as all-cause mortality, myocardial infarction (MI) and repeat coronary revascularisation, and 30 day major bleeding (HORIZONS criteria). Multivariable analyses for MACE and major bleeding comparing procedural P2Y12-inhibitors were performed with Cox proportional hazards models, adjusting for major cardiovascular risk factors.

Results 4056 patients underwent PPCI during the study period, 464 of whom were excluded due to pre-procedural cardiogenic shock and/or cardiac arrest. Data for 30 day bleeding and MACE were available for 3381 of 3592 (94.2\%) patients. Multivariable analysis showed no significant difference in MACE, mortality or major bleeding between patients pre-treated with clopidogrel $(n=1492)$, prasugrel $(n=1152)$, and ticagrelor $(n=737)$ (Table 1$)$. However, there was a significantly lower probability of 30 day MI with ticagrelor compared to clopidogrel (HR 0.38 (0.17-0.84)). The differences in 30 day $\mathrm{MI}$ between prasugrel and clopidogrel (HR 0.59 (0.33-1.04)), and prasugrel and ticagrelor (HR 1.55 (0.673.61)), were not statistically significant. There were no statistically significant differences in mortality between clopidogrel and ticagrelor, between prasugrel and ticagrelor, and between ticagrelor and prasugrel following multivariable analysis.

Conclusion This large consecutive real-world series has shown that pre-treatment with ticagrelor was associated with lower probability of 30 day MI compared to clopidogrel, with no overall difference in bleeding, MACE or mortality. There was no significant difference in bleeding, MACE or mortality between ticagrelor and prasugrel, or between prasugrel and clopidogrel.

Abstract 26 Table 1 Comparison of adjusted MACE, mortality, and bleeding at 30 days according to P2Y12-inhibitor.

\begin{tabular}{|c|c|c|c|}
\hline $\begin{array}{l}\text { P2Y12- } \\
\text { Inhibitor }\end{array}$ & $\begin{array}{l}\text { MACE n (\%) } \\
\text { Adjusted HR (95\% Cl) }\end{array}$ & $\begin{array}{l}\text { Mortality n (\%) } \\
\text { Adjusted HR (95\% CI) }\end{array}$ & $\begin{array}{l}\text { Bleeding n (\%) } \\
\text { Adjusted HR } \\
(95 \% \mathrm{Cl})\end{array}$ \\
\hline $\begin{array}{l}\text { Clopidogrel } \\
(n=1492)\end{array}$ & $161(10.8)$ & $121(8.1)$ & $114(7.6)$ \\
\hline $\begin{array}{l}\text { Ticagrelor } \\
(\mathrm{n}=737)\end{array}$ & $\begin{array}{l}70(9.5) \\
\text { HR } 0.84(0.53-1.32) \text { vs } \\
\text { clopidogrel }\end{array}$ & $\begin{array}{l}56(7.6) \\
\text { HR } 1.01(0.57-1.79) \text { vs } \\
\text { clopidogrel }\end{array}$ & $\begin{array}{l}39(5.3) \\
\text { HR } 0.76(0.41-1.41) \\
\text { vs clopidogrel }\end{array}$ \\
\hline $\begin{array}{l}\text { Clopidogrel } \\
(n=1492)\end{array}$ & $161(10.8)$ & $121(8.1)$ & $114(7.6)$ \\
\hline Prasugrel & $61(5.3)$ & $41(6.9)$ & $59(5.1)$ \\
\hline$(n=1152)$ & $\begin{array}{l}\text { HR } 0.82(0.56-1.20) \text { vs } \\
\text { clopidogrel }\end{array}$ & $\begin{array}{l}\text { HR } 0.95 \text { (0.57-1.57) vs } \\
\text { clopidogrel }\end{array}$ & $\begin{array}{l}\text { HR } 1.25 \text { (0.83-1.87) } \\
\text { vs clopidogrel }\end{array}$ \\
\hline $\begin{array}{l}\text { Ticagrelor } \\
(n=737)\end{array}$ & $70(9.5)$ & $56(7.6)$ & $39(5.3)$ \\
\hline Prasugrel & $61(5.3)$ & $41(6.9)$ & $59(5.1)$ \\
\hline$(n=1152)$ & $\begin{array}{l}\text { HR } 0.97(0.60-1.58) \text { vs } \\
\text { ticagrelor }\end{array}$ & $\begin{array}{l}\text { HR } 0.94(0.50-1.78) \text { vs } \\
\text { ticagrelor }\end{array}$ & $\begin{array}{l}\text { HR } 1.64(0.88-3.05) \\
\text { vs ticagrelor }\end{array}$ \\
\hline
\end{tabular}

\section{USE OF ROTATIONAL ATHERECTOMY IN PRIMARY PCI FOR ST-ELEVATION MYOCARDIAL INFARCTION- A SINGLE CENTRE 10-YEAR EXPERIENCE}

MM Mahmood*, MA Qureshi, R Morley, D Austin, J Carter, MA de Belder, JA Hall, DF Muir, N Swanson, AGC Sutton, P Williams, RA Wright. The James Cook University Hospital

\subsection{6/heartjnl-2017-311726.27}

Introduction Rotational atherectomy (RA) during primary PCI (PPCI) for STEMI is relatively contraindicated because of the perceived increased risk of no-reflow. However, RA PPCI may sometimes be required to restore flow in heavily calcified coronary arteries. Previously only very limited observational data has described the use of RA in PPCI.

Aim We report the clinical and procedural characteristics, and in hospital outcomes, of 21 patients who underwent RA PPCI at our centre between 2006 and 2016,

Methods A retrospective review of the PCI database and medical records.

Results 21 patients (age 78(10) years (mean (SD)), 12 men) underwent RA during PPCI (0.4\% of all PPCI). 3 patients had 